\title{
MODIFIKASI MODEL FORMULASI KEBIJAKAN PERENCANAAN PEMBANGUNAN PERDESAAN BERBASIS PARTISIPASI PUBLIK
}

\author{
Ahmad Sururi \\ Program Studi Ilmu Administrasi Negara Universitas Serang Raya \\ Email: ahmadbroer@gmail.com
}

\begin{abstract}
The purpose of this study was to analyze how the typology of policy formulation solutions in solving public problems and how to model public policy formulation of development planning based on public participation. Research method in this research use qualitative method. This research was conducted in Wanasalam District, Lebak Regency, exactly in Cilangkap Village. Data collection techniques through interviews, observation, documentation and review of documents from various sources and references. Data analysis techniques performed through data reduction, data presentation and data verification. The results and discussion in this research there are 5 (five) solution typology in solving public problem that is: 1)Inducment, policy step that is persuading or pressing over certain issue; 2)Rules, policy measures that emphasize the establishment of rules in the form of regulations that must be adhered to by the community; 3)Facts, policy steps in the form of use of information paths to persuade target groups to want to do something that is considered to solve the problem; 4)Right, policy measures in the form of giving rights or duties to the community; 5)Power. policy efforts in the form of additional weight of power caused by certain demands. Then, the process of modifying the formulation of a public-based rural development planning policy requires synergy between the village government and the community through policy recommendations to the formal policy actors in development planning forums and citizens' debates. The synergy of the three components within the framework of modification of the policy formulation is a continuous process called input (consisting of public choices), the policy process (through Musrenbang and Rembug rakyat forums) and output/outcome (policy formulation of public participation based development planning).
\end{abstract}

Keywords: Modification of Policy Formulation, Policy of Development Planning and Public Participation

\section{PENDAHULUAN}

Potensi daerah perdesaan di Indonesia dengan beragam sumber daya yang dimilikinya merupakan modal yang sangat penting dalam pengembangan tata kelola pembangunan perdesaan. Dukungan semangat kegotongroyongan, kebersamaan dan nilainilai tradisional masyarakat diharapkan dapat menjadi daya ungkit dalam mendorong paradigma pembangunan desa yang bersifat bottom up sehingga memberikan dorongan terhadap penguatan aktor kebijakan pembangunan desa dalam merumuskan kebijakan perencanaan pembangunan.

Perencanaan pembangunan desa sebagaimana diatur dalam Undang-undang
Nomor 6 tahun 2014 tentang desa disusun sesuai dengan perencanaan pembangunan Kabupaten/Kota yang tertuang dalam Rencana Pembangunan Jangka Menengah Desa untuk jangka 6 (enam) tahun dan Rencana Kerja Pemerintahan Desa (RKPD) sebagai penjabaran dari RPJMDesa untuk jangka waktu 1 (satu) tahun. Dalam mekanisme perencanaan pembangunan maka musyawarah perencanaan pembangunan desa dilaksanakan untuk menetapkan prioritas, program, kegiatan, dan kebutuhan Pembangunan Desa.

Sebagai forum dialog, pelaksanaan musyawarah perencanaan pembangunan desa dilaksanakan untuk membahas permasalahan 
strategis pembangunan desa antara pemerintah desa bersama-sama dengan masyarakat. Sinergitas antara pemerintah desa dan masyarakat menjadi bagian yang sangat penting dalam merumuskan kebijakan perencanaan pembangunan. Akan tetapi faktanya proses musyawarah perencanaan pembangunan desa tidak berjalan sesuai dengan prinsip-prinsip sinergitas yang diharapkan, pengambilan keputusan sentralistik masih menjadi faktor dominan dalam proses musyawarah termasuk pengambilan keputusan.

Fakta yang ditemukan di lapangan menunjukkan bahwa masyarakat yang hadir dalam musyawarah desa kurang dilibatkan secara aktif, hal tersebut disebabkan karena keputusan program pembangunan desa terlebih dahulu sudah ditetapkan oleh aparat pemerintahan desa sehingga musyawarah perencanaan pembangunan desa hanya menjadi forum seremonial bagi aparat pemerintahan desa.

Disisi lain perencanaan pembangunan yang tidak melibatkan aspirasi dan partisipasi masyarakat menyebabkan kapasitas masyarakat desa tidak dapat berkembang sehingga pembangunan yang dilaksanakan kurang memiliki faktor dampak dan manfaat yang mendorong penguatan kapasitas masyarakat baik secara individu maupun kelompok. Oleh sebab itu urgensi penguatan kapasitas masyarakat melalui tata kelola formulasi kebijakan perencanaan pembangunan menjadi penting dan perlu terus untuk didorong. Konsep pendekatan yang memandang inisiatif kreatif dari rakyat sebagai sumber daya pembangunan yang utama dan memandang kesejahteraan material dan spiritual mereka sebagai tujuan yang ingin dicapai oleh proses pembangunan (Korten dan Corner, 1987:61), dapat terealisasikan melalui tata kelola kebijakan perencanaan pembangunan dengan mengedepankan kekuatan kolektif dari berbagai individu dan komunitas yang berasal dari ide dan gagasan masyarakat lokal dengan menempatkan anggota masyarakat selaku aktor kebijakan pembangunan

Pembangunan adalah suatu usaha atau perubahan, demi tercapainya tingkat kesejahteraan atau mutu hidup suatu masyarakat serta individu-individu didalamnya yang berkehendak dan melaksanakan pembangunan itu. (Riyadi, 1981 dalam Mardikanto dan Soebiato, 2014:3). Sebagai sebuah upaya menuju tercapainya kesejahteraan, masyarakat perdesaan adalah subjek perencanaan pembangunan karena pembangunan mensyaratkan pelibatan atau partisipasi seluruh warga masyarakat sejak pengambilan keputusan perencanaan pembangunan sampai pada pelaksanaan dan pengawasan kegiatan serta pemanfaatan hasil-hasilnya oleh masyarakat (Mardikanto \& Soebiato, 2014:5).

Pentingnya perencanaan pembangunan yang melibatkan masyarakat merupakan sebuah kondisi objektif dikarenakan masyarakat adalah pihak yang paling mengetahui kebutuhan pembangunan dan memahami permasalahan-permasalahan sehingga dalam hal ini terdapat 5 (lima) tipe solusi yang perlu diformulasikan dalam kebijakan yaitu : 1)Inducment, langkah kebijakan yang bersifat membujuk atau menekan atas isu tertentu; 2)Rules, langkah kebijakan yang menekankan pada pembentukan aturan-aturan dalam bentuk regulasi-regulasi yang harus ditaati oleh masyarakat; 3)Facts, langkah kebijakan berupa penggunaan jalur informasi untuk mempersuasi kelompok target agar mau melakukan sesuatu yang dianggap menyelesaikan masalah; 4)Right, langkah kebijakan berbentuk pemberian hak-hak atau tugas-tugas pada masyarakat; 5)Power, upaya kebijakan berupa penambahan bobot kekuasaan yang disebabkan adanya tuntutan tertentu. (Deborah Stone dalam Lester dan Stewart, 2000 dalam Kusumanegara, 2010:87). Kelima tipe solusi tersebut dapat menjadi problem solving bagi pemangku kebijakan dalam memecahkan permasalahan- 
permaslahan publik dalam tahap perencanaan pembangunan.

Pembangunan dengan berbasis partisipasi masyarakat dimaknai sebagai the continued active involvment of citizen in making which affect them (Antoft dan Novack, 1988). Proses keberlanjutan tersebut menjadi sesuatu yang penting guna mendukung keberhasilan tujuan pembangunan melalui masyarakat sebagai aktor perencana. Hasil penelitian dari Ricky Irawan, Mardiyono dan Ratih Nurpratiwi (2015) tentang partisipasi masyarakat dalam perencanaan pembangunan daerah menyebutkan bahwa partisipasi masyarakat dalam Musrenbang adalah hadir dan aktif serta terdapat sinergi antar pemerintah dengan masyarakat dalam kegiatan perencanaan pembangunan. Hal tersebut menunjukkan bahwa sinergitas dalam meningkatkan kualitas perencanaan desa diperlukan tata kelola formulasi kebijakan yang tepat dan terukur serta melibatkan masyarakat sebagai stakeholder pembangunan.

Kemudian dalam penelitian yang dilakukan oleh Armando Soares, Ratih Nurpratiwi dan M. Makmur (2015) memberikan kesimpulan bahwa pemerintah daerah berperan sebagai entrepreuneur, koordinator, fasilitator dan stimulator yang melibatkan semua stakeholder untuk berpartisipasi dalam pembangunan daerah untuk melakukan verifikasi, mengevaluasi dan supervisi terhadap program prioritas perencanaan pembangunan daerah. Dengan demikian dapat dikemukakan bahwa partisipasi masyarakat merupakan instrumen penting dalam proses pembangunan melalui berbagai potensi dan sumber daya yang ada.

Formulasi kebijakan akan sangat membantu para analis kebijakan untuk menemukan asumsi-asumsi yang tersembunyi, mendiagnosis penyebagianpenyebagian masalah publik, memetakan tujuan-tujuan yang memungkinkan, memadukan pandangan-pandangan yang bertentangan dan merancang peluang-peluang kebijakan yang baru (Dunn, 1999:26 dalam
Agustino, 2006:97). Dalam kaitannya dengan perencanaan pembangunan perdesaan, maka model formulasi kebijakan melalui pilihan publik merupakan salah satu opsi yang tepat karena pada intinya setiap kebijakan publik yan dibuat oleh pemerintah harus merupakan pilihan dari publik yang menjadi penguna (beneficiaries atau customer dalam konsep bisnis). Proses formulasi kebijakan publik dengan demikian melibatkan publik melalui kelompok-kelompok kepentingan (Riant Nugroho, 2003:132). Publik dalam hal ini dimaknai sebagai masyarakat desa yang terdiri dari berbagai kelompok seperti kelompok tani, kelompok pedagang, kelompok wanita, kelompok pemuda, kelompok buruh tani, dan berbagai komunitas lainnya yang mempunyai kepentingan. Selain itu dalam analisis formulasi kebijakan terdapat modifikasi model sistem dalam proses kebijakan sebagaimana dikemukakan oleh Jenkins (2003) dalam Kusumanegara (2010:95) bahwa dalam model sistem pembuatan keputusan terletak dalam sistem politik dimana di dalamnya terdapat berbagai aktor-aktor formal perumusan kebijakan publik yaitu aparat pemerintah desa, tuntutantuntutan, sumber daya dukungan dan dukungan, kelompok-kelompok kepentingan, sistem keputusan, output dan hasil kebijakan.

Tujuan penelitian ini adalah untuk menganalisis bagaimana tipologi solusi formulasi kebijakan dalam penyelesaian masalah publik dan bagaimana model formulasi kebijakan perencanaan pembangunan perdesan berbasis partisipasi publik.

\section{METODE PENELITIAN}

Metode penelitian dalam penelitian ini menggunakan metode kualitatif yaitu prosedur penelitian yang menghasilkan data deskriptif berupa kata-kata tertulis atau lisan dari orang-orang dan perilaku yang diamati (Bogman dan Taylor dalam Moleong, 2005:3). Penelitian ini dilakukan di Kecamatan Wanasalam Kabupaten Lebak tepatnya di Desa Cilangkap dimana 
pelaksanaan musyawarah Perencanaan Pembangunan Desa yang dilaksanakan belum berdampak terhadap akses kebutuhan dasar masyarakat desa. Teknik pengumpulan data melalui wawancara, observasi, dokumentasi dan telaah dokumen-dokumen dari berbagai sumber dan referensi. Teknik analisis data dilakukan melalui reduksi data, penyajian data dan verifikasi data.

\section{HASIL DAN PEMBAHASAN}

\section{Tipologi Formulasi Kebijakan dalam penyelesaian permasalahan perencanaan pembangunan berbasis partisipasi masyarakat.}

Dalam konteks penelitian ini, analisis tipologi formulasi kebijakan yang perlu dilakukan dalam penyelesaian permasalahan perencanaan pembangunan berbasis partisipasi publik di Desa Cilangkap Kecamatan Wanasalam adalah sebagai berikut

a. Inducment, sebuah langkah kebijakan yang bersifat membujuk dalam mengatasi isu-isu tertentu yang berkembang di masyarakat. Posisi masyarakat yang cenderung pasif dan tidak merespon upaya-upaya perencanaan pembangunan merupakan akibat dari kurangnya langkah-langkah persuasif dari pemerintah desa untuk melibatkan masyarakat. Berdasarkan data wawancara dan observasi dapat disimpulkan bahwa selama ini masyarakat tidak mengetahui bagaimana perencanaan pembangunan dilakukan, untuk apa dan bermanfaat untuk siapa. Masyarakat diposisikan secara pasif dalam proses pembangunan dan tidak pernah dilibatkan dalam musyawarah dan rembug warga untuk membahas permasalahan kebutuhan pembangunan.

b. Rules, langkah kebijakan yang menekankan pada pembentukan aturanaturan dalam bentuk regulasi-regulasi yang harus ditaati oleh masyarakat dan diinisasi oleh pemerintah desa menjadi salah satu prasyarat dalam kebijakan perencanaan pembangunan akan tetapi berdasarkan data observasi dapat disimpulkan bahwa aturan dan regulasi yang dibuat tidak melibatkan masyarakat dalam proses pembuatannya. Kewenangan pemerintah desa sebagai regulator dalam hal ini dimaknai secara absolut dan kurang memperhatikan aspirasi yang berkembang di masyarakat sehingga berdampak pada ketidaktaatan masyarakat terhadap aturan dan regulasi yang telah dibuat. Hasil wawancara menyebutkan bahwa masyarakat tidak setuju dengan aturan dan regulasi yang dibuat karena hanya menguntungkan beberapa pihak saja atau kelompok-kelompok tertentu saja sedangkan kelompok-kelompok lain merasa dirugikan seperti kebijakan pemilihan pembangunan akses jalan kampung yang dilakukan secara tidak merata dan hanya dilakukan pada beberapa jalan kampung yang berdekatan dengan pemerintah desa sedangkan akses jalan kampung ke rumah-rumah warga tidak diperhatikan.

c. Facts, langkah kebijakan berupa penggunaan jalur informasi untuk mempersuasi masyarakat atau kelompokkelompok dalam masyarakat agar mau melakukan sesuatu sesuai dengan keinginan pemerintahan desa berupa sosialiasi dan komunikasi kepada masyarakat belum dilakukan secara transparan, akuntabel dan konsisten. Masyarakat mengetahui beberapa sosialisasi yang ditempel di kantor pemerintah desa akan tetapi tidak menjelaskan maksud dan tujuan dari isi sosialisasi tersebut. Data hasil wawancara kepada beberapa warga masyarakat menyebutkan sosialisasi dan pengumuman tidak hanya berlangsung beberapa hari saja dan tidak ada keterbukaan dari pemerintahan desa tentang sosialisasi tersebut.

d. Right, langkah kebijakan berbentuk pemberian hak-hak atau tugas-tugas pada masyarakat agar terlibat dalam proses 
perencanaan pembangunan tidak melibatkan secara aktif masyarakat. Representasi masyarakat yang terdiri dari berbagai profesi, kelompok dan berbagai kampung tidak dilakukan, pemerintah desa hanya memberikan tugas kepada sebagian kecil warga saja. Hal tersebut menyebabkan terjadinya kecemburuan sosial di masyarakat karena tidak pernah merasa dilibatkan.

e. Power, upaya kebijakan berupa penambahan bobot kekuasaan yang disebabkan adanya tuntutan tertentu. Secara praktis masyarakat dengan berbagai saluran komunikasi melalui tokoh-tokoh masyatakat, tokoh agama dan tokoh pemuda berupaya untuk mendorong proses perencanaan pembangunan yang transparan. Berdasarkan hasil wawancara dan observasi dapat disimpulkan, upayaupaya tersebut sudah dilakukan akan tetapi masih belum dapat terealisasikan, masyarakat sebagai pihak yang paling mengetahui permasalahan kebutuhan pembangunan berupaya agar setiap proses perencanaan pembangunan dilakukan secara transparan dan akuntabel sehingga dapat memuaskan semua pihak.

2. Modifikasi Model Formulasi Kebijakan Perencanaan Pembangunan Perdesaan Berbasis Partisipasi publik

Model pilihan publik merupakan opsi yang tepat dalam formulasi kebijakan perencanaan pembangunan berbasis partisipasi publik. Proses formulasi kebijakan publik dengan demikian melibatkan publik melalui kelompok-kelompok kepentingan (Riant Nugroho, 2003:132). Di Desa Cilangkap Kecamatan Wanasalam terdapat berbagai kelompok masyarakat yang mempunyai kepentingan secara langsung terhadap proses pembangunan, kelompokkelompok tersebut yaitu, kelompok petani, kelompok buruh tani, kelompok pengusaha, kelompok perempuan, kelompok pemuda, kelompok pengajian, kelompok buruh ladang dan kebun dan kelompok pedagang. Dalam penelitian ini, pengelompokan perlu dilakukan dengan tujuan mengakomodir berbagai kepentingan dengan tetap memperhatikan bahwa masing-masing kelompok tersebut tersebar dan bertempat tinggal di berbagai dusun tetap menjadi perhatian fokus perencanaan pembangunan. Berikut adalah modifikasi model pilihan publik dan model sistem Formulasi kebijakan perencanaan pembangunan berbasis publik.

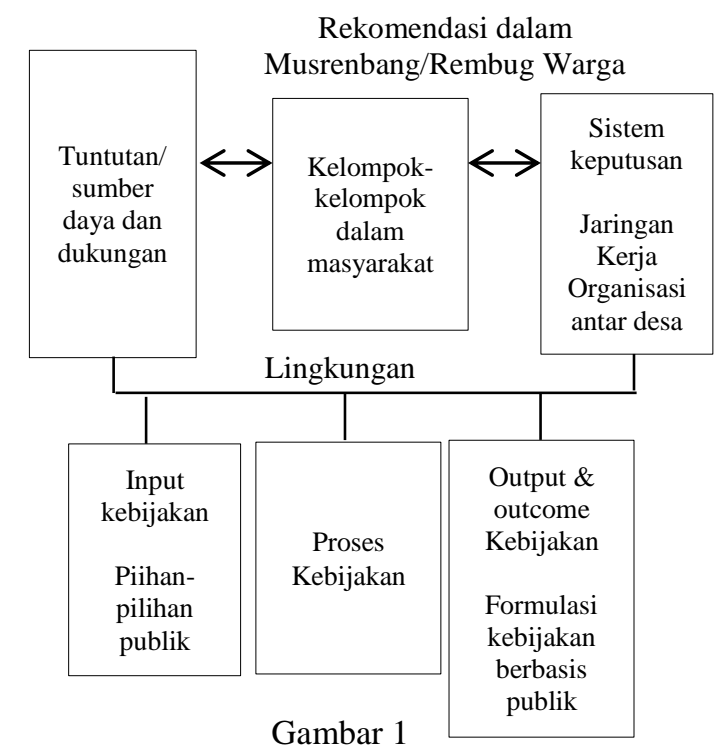

Modifikasi Formulasi Kebijakan Perencanaan

Pembangunan Perdesaan Berbasis Partisipasi Publik (diadaptasi dari model sistem Easton, (1982) dan Jenkis (1993)

Dari gambar 1 tersebut dapat dijelaskan bahwa proses formulasi kebijakan perencanaan pembangunan perdesaan berbasis publik diawali dengan adanya tuntutan-tuntutan dari berbagai elemen dengan didukung oleh ketersediaan sumber daya. Ketiga elemen tersebut merupakan faktor pendorong bagi kelompok-kelompok yang terdapat di masyarakat untuk mendorong dan menekan pemerintahan desa agar dilibatkan dan ambil bagian dalam proses kebijakan perencanaan pembangunan melalui rekomendasi kebijakan dalam forum-forum musyawarah perencanaan pembangunan dan rembug-rembug warga, kelompok-kelompok di masyarakat tersebut adalah kelompok tani, buruh tani, kelompok pedagang, kelompok perempuan, kelompok pemuda dan kelompok pengajian. Selanjutnya hasil rekomendasi 
tersebut diajukan kepada aktor formal kebijakan dalam hal ini adalah aparat pemerintah desa untuk mengambil keputusan melalui jaringan kerja organisasi antara desa.

Sinergitas ketiga komponen tersebut dalam kerangka modifikasi formulasi kebijakan merupakan sebuah proses berkelanjutan yang terdiri dari input (terdiri dari pilihan-pilihan publik), proses kebijakan (melalui forum Musrenbang dan Rembug warga) dan output/outcome (formulasi kebijakan perencanaan pembangunan berbasis partisipasi publik).

\section{KESIMPULAN}

Tipologi solusi formulasi kebijakan dalam penyelesaian masalah publik dan model formulasi kebijakan perencanaan pembangunan perdesan berbasis partisipasi publik merupakan sebuah proses kebijakan yang berkelanjutan dalam sebuah mekanisme yang sinergis antar stakeholders yang terdiri dari publik sebagai aktor non formal kebijakan perencanaan pembangunan perdesaan dan pemerintahan desa sebagai aktor formal kebijakan. Proses keberlanjutan tersebut akan berjalan dengan baik dimulai dari tahapan penyelesaian permasalahan publik sampai dengan modifikasi formulasi kebijakan publik.

Sebagai sebuah opsi kebijakan perencanaan, model pilihan publik dan model sistem dianggap cukup tepat dalam kebijakan perencanaan pembangunan dengan publik sebagai aktor utama pembangunan. Secara empiris, publik

Perencanaan Pembangunan perdesaan perlu dilakukan melalui sinergitas antar aktoraktor kebijakan formal dan non formal secara konsisten dan berkelanjutan. Diperlukan dorongan dan kesadaran dari berbagai aktor tersebut untuk berperan sesuai dengan kapasitas dan kapabilitasnya. Dengan demikian pembagian peran yang dilakukan secara sinergis akan menciptakan tata kelola perencanaan pembangunan yang mengedepankan asas kebersamaan dan prinsip-prinsip akomodatif demi tercapainya tujuan pembangunan.

Model pilihan publik dan terintegrasinya sebuah sistem kebijakan yang terdiri dari input, proses dan output dapat menjadi sebuah pilihan bagi perencaanaan kebijakan pembangunan dengan tetap mengutamakan prinsip-prinsip transparansi dan akuntabilitas.

\section{DAFTAR PUSTAKA}

Agustino, Leo, 2014. Dasar-dasar Kebijakan Publik, Alfabeta, Bandung.

Antoft K, \& Novack J, 1998. Grassroots Democracy: Local Government in the Maritimes, Nova Scotia Henson College Dollhouse University

Kusumanegara, Solahudin, 2010. Model dan Aktor dalam Proses Kebijakan Publik, Gava Media, Yogyakarta.

Korten David \& Syahrir, 1987. Pembangunan Berdimensi Kerakyatan, Jakarta, Yayasan Obor Indonesia

Mardikanto T dan Soebiato P, 2013, Pemberdayaan Masyarakat dalam Perspektif Kebijakan Publik. Alfabeta, Bandung.

Nugroho, Riant, 2003. Kebijakan Publik, Formulasi, Implementasi dan Evaluasi, PT. Elex Media Komputindo Gramedia, Jakarta.

Ricki Irawan, Mardiyono, Ratih Nurpratiwi, Partisipasi Masyarakat dalam Perencanaan Pembangunan Daerah, Jurnal Ilmu Sosial dan Ilmu Politik ISSN. 2442 -6962, Vol. 4, No. 2 (2015)

Armando Soares, Ratih Nurpratiwi dan M. Makmur, Peranan pemerintah daerah dalam perencanaan Pembangunan daerah, Jurnal Ilmu Sosial dan Ilmu Politik ISSN. 2442-6962 Vol. 4, No. 2 (2015) 